\title{
Financial Knowledge, Digital Financial Knowledge, Financial Attitude, Financial Behaviour and Financial Satisfaction on Millennials
}

\author{
Rani Arifah Normawati ${ }^{1}$, Sri Mangesti Rahayu ${ }^{2}$, Saparila Worokinasih ${ }^{3}$ \\ Departement of Business Administration, Faculty of Administrative Science, \\ Brawijaya University, Malang ${ }^{1,2,3}$ \\ \{raniarifahnormawati@gmail.com¹,sri_mangesti@yahoo.com2,saparila.fia@ub.ac.id ${ }^{3}$ \}
}

\begin{abstract}
The increase of digital financial services has created new risks for its users. As a generation close to technology, the millennial generation with all its characteristics, financially vulnerable to this risk. Millennials face financial management problems because of their characteristics, coupled with the complexity of digital financial services that exist today. This concern leads to explain and predict millennial financial satisfaction associated with financial behavior, financial attitudes, financial knowledge, and digital financial knowledge, an area that has not been tackled critically in literaturere. This study attempts to formulate a conceptual framework and a research model developed with the TRA and TPB theory. The conceptual formulation method and model were carried out in several stages; literature study, model adoption, and instrument development. The results of the instrument development can be used for further research.
\end{abstract}

Keywords: Millenials; Digital Financial Knowledge; Financial Satisfaction

\section{Introduction}

The invention of technology dominates the use of technology and changes almost all structures of life, including financial activities. The emergence of various digital financial services (DFS) provides benefits to consumers and entrepreneurs, including; offers transactions that are more convenient, easier, faster, safer, more accurate, and timely, on the other hand, that can improve business process efficiency, reduce costs, and increase customer satisfaction [1], [2]. The consequence of the development of digital financial services is new risks that may not have existed before.

Fintech and digital financial services are developed based on peer-to-peer, which grows under a decentralized nature. Decentralization means that the total decision-making process is left to users. Therefore, financial knowledge and digital financial knowledge, are needed to support financial decisions. Digital financial knowledge is closely related to financial knowledge. So, understanding digital financial knowledge requires an initial understanding of financial knowledge [3], [4]. 
Digital financial knowledge is very necessary so that users can take advantage of these services, preventing users from emerging risks such as misperceptions in buying and selling, fraud, hacking, misuse of data and information, and also issues of financial behavior (financial behavior), for example, making excess borrowing [4].

Digitalization and all its implications are very close to the millennial generation. As a generation born and raised in technological advances, millennials have greater potential in using technology than previous generations. In the financial sector, millennials are introduced to digital financial services earlier, such as online purchases and online payments [5].

On the other hand, the gig economy phenomenon has become an alternative and great demand by millennials. This trend is marked by the emergence of temporary jobs with shortterm contracts and direct contracts to each individual. Its means that millennials must be responsible for their respective financial planning.

Millennials also tend to behave consumptively. Millennials also tend to behave consumptively. In 2019, IDN report millennials only saved $10.7 \%$ of their income, and nearly $51.1 \%$ was used up for monthly needs [6]. This reinforces that a person must have good financial behavior, be able to manage his income, and save it for his retirement. Financial behavior will be strengthened by financial attitude. Financial attitude is a state of thinking, opinion, and judgment about finance. An individual's attitude can lead to behavior [7].

Currently, millennials are financially in a vulnerable position. Based on various existing studies, millennials also tend to experience problems in financial management. Millennials not only face complexity of digital financial products and services, but they will also bear greater financial risks in the future if they are not equipped with financial knowledge or digital financial knowledge that underlies their financial attitude and financial behavior.

Existing studies show a relationship between financial knowledge and financial behavior [8], [9], [10], [7], [11]. To build good financial behavior, a person must have good financial knowledge. Another study also shows the relationship between financial attitude and financial behavior. This study was conducted by Kirbis and Arifin [12], [7]. These three aspects, namely knowledge, attitude, and behavior, are of concern in strengthening financial literacy in general and digitally.

Financial knowledge, both basic and digital is necessary as individual responsibility increases to secure their long-term financial well-being. So are financial attitudes and behaviors. This is necessary for the context of their financial decision-making process [13]. Financial well-being is closely related to financial satisfaction. Financial satisfaction in the present can be a predictor of financial well-being in the future. It is important to know a person's financial attitude and financial behavior, ensure that someone has a positive and responsible financial attitude and financial behavior to promote financial well-being and achieve greater financial satisfaction [14].

Concern about millennial behavior leads to the need to explain and predict the personal financial satisfaction of millennials. By understanding the factors that affect the financial satisfaction of millennials, it can be a consideration for researchers, practitioners, and public policymakers to formulate strategies or even develop more effective education to increase the life satisfaction of future millennial generations. Thus, financial satisfaction involves being healthy, happy, and free from financial worries [15], [8]. This is important because it cannot be denied that millennials will be the largest population compared to other generations. Therefore, if this potential can be maximized, it will be able to increase economic growth [16]. 


\section{Conceptual Framework and Previous Research}

\subsection{Financial Knowledge}

Financial literacy is conceptualized using two dimensions, same with literacy in general, or literacy in the world of health. These dimensions are the knowledge dimension and the application dimension [17]. Financial knowledge is a part of financial literacy which refers to a basic understanding of financial concepts [18].

Previous research has shown that financial knowledge is a predictor of financial wellbeing, stated by Archuleta et al., 2013; Norvilitis and MacLean, 2010 in Saurabh and Nandan [11]. Still, in Saurabh and Nandan, Mugenda et al. (1990) concluded that there is still a negative relationship between financial knowledge and financial satisfaction.

Financial knowledge also affects financial behavior. Someone who has financial knowledge can evaluate the information received before using the information to its advantage. According to Perry and Morris, financial knowledge has a great influence on financial behavior, because someone who has extensive financial knowledge will be more responsible for their financial behavior. Meanwhile, Chen and Volpe stated that individuals with a high level of financial knowledge tend to have the right opinion and make good decisions regarding investment, savings management, and debt management [11].

Several previous studies have identified that financial knowledge is one of the important factors that can improve financial behavior which in turn will affect financial well-being. Joo developed a financial satisfaction model which states that financial knowledge and financial behavior together can change an individual's perception of their financial satisfaction [9].

\subsection{Digital Financial Knowledge}

Digital financial literacy has become a concern, both the government, financial service companies, and the public since the rise of digital financial services (DFS)[19]. DFS can be defined as financial operations that use digital technology. Example of this operation is including electronic money, financial mobile services, online financial services, i-tellers, and branchless banking, both through bank and non-bank institutions. DFS can cover a wide range of monetary transactions such as deposits, withdrawals, sending and receiving money, including payments, credit, savings, pensions, and insurance. DFS can also cover nontransactional services, such as viewing personal financial information via digital devices [20].

Digital financial literacy is directly related to knowledge related to online purchases, online payments, and online banking [3]. Digital financial knowledge is a multi-dimensional financial knowledge concept that includes financial knowledge and digital knowledge [21]. While Tony in his research stated that digital financial literacy has the same basis as financial literacy and added digital aspects [22].

The OECD describes the main competencies in digital financial literacy proposed in the policy guidelines for countries members of the G20. The first competency is trust in DFS including awareness of the benefits and risks of various types of digital financial products and services for personal or business purposes (e.g. e-money, mobile banking, crowdfunding, peer-to-peer lending, digital credit and insurance services, cryptocurrency, etc.). The next is an awareness of informal and unregulated financial products and services (e.g. some blockchainbased technologies such as cryptocurrencies, initial coin offerings, etc.); The last, knowledge of consumer rights in the digital world, understanding of the implications of signing digital contracts, and the terms and conditions proposed. The second competency concerns data risk, 
which includes managing personal information and assessing requests for information. In this case, the user must be able to assess the type of information requested by the financial service provider to decide relevantly and understand how the information will be stored and used. The third competency is related to the risk of dependency due to easy access, including the awareness that simple online marketing and lending processes can increase shopping and lending, an awareness that usage history can be used to provide other promotions through price sensitivity, request for credit back and repayment, awareness of costs on the use of digital credit facilities, knowledge of various digital credits, and understanding of regulations and consumer protection related to the products they use. Furthermore, Morgan considers that knowledge of digital crimes is important so that consumers and entrepreneurs avoid crimes and misuses such as online fraud, phishing, social engineering fraud, account hacking attacks, or data theft [22].

Meanwhile, Peter J. Morgan, Bihong Huang, Long Q. Trinh from the Asian Development Bank Institute proposed the dimension of digital financial literacy. There are four dimensions, such as :

a. Digital products and services, a basic understanding of digital products and services that exist today, realizing the difference with traditional products and services;

b. Digital financial risk: additional risk when using digital products and services, the risk of using these products and services is greater than using traditional products and services. Possible risks arising such as phishing, pharming, spyware, SIM card swaps. Also, people must understand that there are digital traces when they access the internet, so people need to understand things like hacking and profiling. On the other hand, by the ease of access, there is the possibility of overborrowing risks and high-interest rates. Therefore, it is very important for users to fully understand the contracts they sign, in addition to other points contained in the contract, such as access to data usage for third parties;

c. Digital financial risk control; the understanding of all risks posed by the use of digital products and services, for example how to secure passwords or PINs and secure their personal information when using digital products and services;

d. Consumer rights and redress procedure; if users of digital products and services bear the risks above, users must know their rights as consumers, know where to complain, and how to take care of compensation if they become victims or suffer losses [4].

\subsection{Financial Attitude}

The research written by Arifin, states that attitude is a psychological tendency that is most easily expressed in the form of likes or dislikes [7]. Attitudes that lead to a certain behavior can be seen from the assessment of whether the attitude supports a behavior or vice versa. Rajna in Arifin states that attitude is a person's feelings, thoughts, and tendencies towards certain aspects that are most visible, whether pleasant or unpleasant, towards objects, individuals, and events. Financial attitude is a state of thought, opinion, and judgment about finances [7]. In the OECD report, it is stated that the knowledge and ability to do something in a certain way is influenced by the attitude of the individual [20].

Financial Attitude is a predisposition to behave in a certain way that is formed because of several economic and non-economic beliefs that individuals have as a result of certain behaviors [23], [24]. OECD / INFE, states that one of the definitions of financial literacy includes financial attitude. Even if a person has sufficient knowledge and ability to act in a certain way, their attitude will influence the decision to do or not do something, so that the 
combination of awareness, knowledge, skills, attitude, and behavior will determine the financial decisions, which in the end obtained individual financial welfare [25].

Individuals with a high financial attitude tend to have a positive attitude towards financial planning. Someone with a high financial attitude also tends to save, not consumptive, and plan for retirement [24]. In financial literacy, financial attitude is measured to see its effect on financial decisions on money and financial planning in the future [20].

Anthony stated that to measure financial attitude, eleven statements could be used, namely; (a) The importance of the habit of saving; (b) The importance of financial goals; (c) The importance of planning a budget; (d) Attitudes towards financial welfare responsibilities; (e) saving is not important; (f) As long as you have permanent income, it does not matter if you have long-term debt; (g) Attention to the amount set aside for savings; (h) Views regarding financial planning at retirement; (i) Salary planning if you have a disability; (j) Insurance for property owned; (k) Financial picture for the next five or ten years [26].

\subsection{Financial Behavior}

According to Britt et al. in Saurabh \& Nandan, financial behavior refers to the financial management techniques. Meanwhile, Loix et al, stated that financial behavior refers to the handling of a person's income and financial situation. In other words, financial behavior is the individual's orientation towards daily financial problems [11]. Falahati said that financial behavior means an individual's ability to manage his finances to be successful in his life [9]. A person's financial behavior will greatly affect their financial well-being. Therefore, it is imperative to capture evidence for the behavioral dimensions of financial literacy measures.

Robb and Woodyard in Saurabh \& Nandan define several financial practices as positive financial behavior, such as preparing a budget for expenses, saving for the short and long term, and making provisions for emergency funds [11]. Previous research has shown that individual financial behavior is a major determinant of their financial satisfaction [8], [9], [27], [28], [29]. Dowling et al in Saurabh \& Nandan, individual financial behavior has a positive influence on their financial satisfaction and a negative influence on their financial pressure [11].

\subsection{Financial Satisfaction}

Ed Diener in The Science of Well Being (SWB) states that a good life is closely related to subjective well-being, a person's expectations about the life he wants, regardless of the views of others. In SWB it is stated that happiness is obtained when several conditions such as needs and goals can be achieved. One of the postulates put forward by Wilson (1967) is that satisfaction on needs causes happiness and vice versa, if needs are not sufficed, it will cause unhappiness [30].

Satisfaction is associated with individual satisfaction such as health, finance, and work. The satisfaction domain is a cognitive component of subjective well-being, this is mentioned in Diener. Subjective well-being shows happiness, life satisfaction, and evaluation of life such as work, health, and relationships. In Arifin, it was stated that financial satisfaction is part of the satisfaction domains [7].

Financial satisfaction is an integral component of financial well-being, related to psychological well-being. While, Joo and Grable, state that financial satisfaction is the satisfaction that refers to a person's feelings regarding all aspects of their financial situation, 
especially income, the ability to meet primary needs, and the ability to take action during financial emergencies [8], [11].

Hira and Mugenda in Arifin stated that satisfaction is measured through savings, loans, current financial condition, ability to meet long-term needs, funds for sudden needs, and financial management skills. Meanwhile, Xiao in Arifin measures financial satisfaction with a single question, "how satisfied are you with your current financial condition". Draughn et al (1994) stated that economic satisfaction consists of three components: (1) financial adequacy related to income adequacy, (2) perceptions of economic well-being, subjective assessment of economic viability, and (3) satisfaction with the level of life, specifically the perception of an individual's ability to meet financial demands [7].

\section{Methodology}

This study was developed in three stages (Figure 1). First, collect then review the literature and previous study. Then, they are analyzed and adopted to be formulated into a research model. The third is instrument development. At this stage, each in the variable is explained, including compiling measurement item.

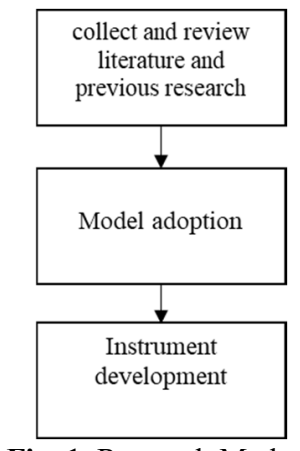

Fig. 1. Research Method

\section{Result and Discussion}

The grand theory in this study is Theory of Reasoned Action (TRA) by Fishbein and Ajzen and has been developed into Theory of Planned Behavior (TPB) by Ajzen. Both of these theories explain human behavior. This theory is structured using the basic assumption that humans behave consciously and consider all available information.

The relationship between financial knowledge and digital financial knowledge with financial behavior adopts the TPB as suggested by Ajzen (1985). In this theory, rational action is based on the assumption that humans act logically, consider all available information, and calculate directly and indirectly [31].

An attitude can lead to behavior that refers to judgments that support or do not support the behavior to be carried out. This refers to the TRA proposed by Fishbein and Ajzen in 1975. Financial attitude has an important role in determining the success or failure of a financial behavior [7]. If the individual's thinking about finances is good, then he will be responsible for his financial condition, have the desire to save, invest and plan for a better future. 
TPB is also relevant to be used to explain how high a person's confidence is when he performs a certain behavior. From this belief, he will decide whether to carry out his behavior or not. This level of trust is associated with a person's level of awareness. If someone has high awareness, they will have the intention to do. From this, an individual will take action. If the planned actions are achieved, they will get satisfaction from the results of the behavior [7].

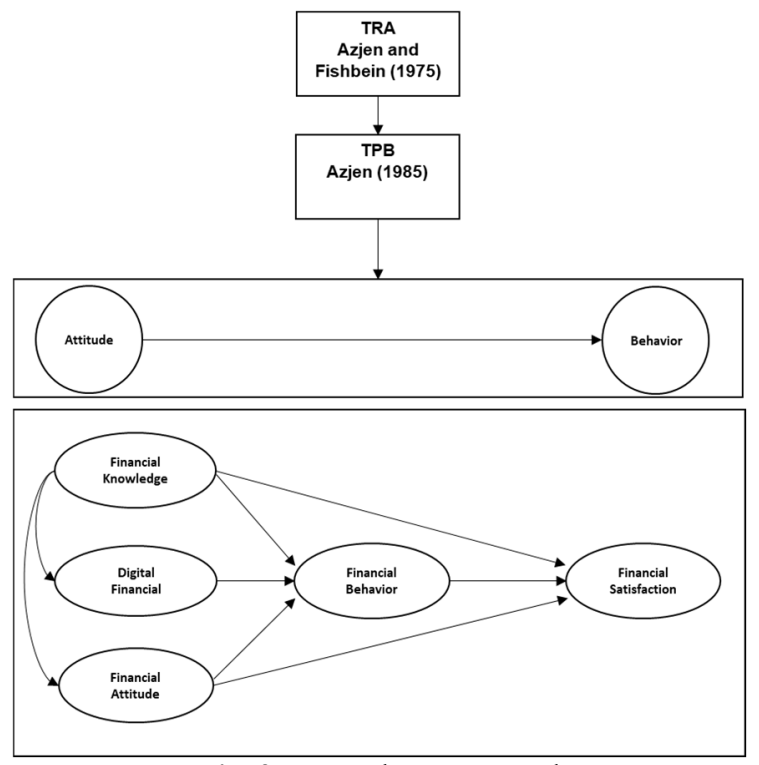

Fig. 2. Kerangka Konseptual

\section{a) Financial Knowledge}

Financial knowledge refers to understanding the basic of financial concepts. Huston identified the financial knowledge component after reviewing 71 studies, namely; basic concepts of money, purchasing power, personal financial accounting concepts, and transfer of resources between periods, which include loans, savings, and investments, protection (Huston, 2010a). In this study, s were adopted from Huston, Garg \& Singh, OECD / INFE, OJK, and Augustin [17], [24], [32], [33], [34] .

Table 1. Indicator and Item of Financial Knowledge

\begin{tabular}{ll}
\hline \multicolumn{1}{c}{ Indicator } & \multicolumn{1}{c}{ Item } \\
\hline 1. Basic Concept of Money & 1. Simple arithmetic in a financial context \\
& 2. Time value of money \\
3. Simple interest rates \\
4. Compound interest rates \\
5. Inflation \\
6. The impact of inflation on the price level \\
7. The impact of inflation on investment returns \\
2. Purchasing power & 2. Purchasing power concept \\
& 3. Loan on purchasing power \\
3. Personal financial & 4. Intention on purchasing power \\
& 1. Benefits of the basics financial knowledge
\end{tabular}




\begin{tabular}{ll}
\hline \multicolumn{1}{c}{ Indicator } & \multicolumn{1}{c}{ Item } \\
\hline management & 2. Source of income \\
& 3. Source of expenditure \\
4. Personal finance management \\
5. Budgeting \\
6. Financial Goals \\
7. Financial Plan \\
4. Saving and investment & 2. Administrative requirements for opening savings at a bank \\
& 3. Minimum deposit when opening saving \\
4. Minimum deposit saving \\
5. Government guarantee \\
6. Investing in stocks \\
7. Investing in bonds \\
8. Investing in mutual funds \\
1. Lender \\
2. Loan term \\
3. Loan scheme \\
4. Loan interest \\
5. Loan cost \\
1. Insurance purpose \\
2. Insurance requirements \\
3. Considerations in choosing the type of insurance \\
4. Insurance premiums \\
\end{tabular}

\section{b) Digital Financial Knowledge}

Digital financial knowledge is financial knowledge seen from the media used, that is digital media. Very few studies have investigated the actual impact of digital knowledge, especially related to financial literacy [19] and there is no generally accepted standard. Therefore, the $\mathrm{s}$ that can be used are adopting the policy guidelines presented by OEDC, 2018 and Morgan, 2019 [1], [4].

Table 2. Indicator and Item of Digital Financial Knowledge

\begin{tabular}{ll}
\hline \multicolumn{1}{c}{ Indicator } & \\
\hline 1. Trust on DFS & 1. Knowledge of DFS \\
& 2. Knowedge od DFS nature \\
& 3. Consumer rights knowledge in the digital world \\
2. Personal information & 1. Implications of signing a digital contract \\
risk & 2. Assessment of information requests \\
3. Addiction risk & 1. Awareness of financial behavior-changing \\
& 2. Promotion awareness of usage history; \\
& 3. Awareness of costs for using digital credit facilities; \\
& 4. Knowledge of how to research and compare various financial products; \\
& 5. Understanding of regulation and protection \\
4. Digital crimes & 2. Awareness of online fraud and cybersecurity risks; \\
& 3. Kwareness of the possibilities offered by the account aggregation tool; \\
& 4. Knowledge of compensation mechanisms;
\end{tabular}




\section{c) Financial Attitude}

Financial attitude represents thoughts, opinions, and judgments about finance. The measurement of financial attitude is adopted from the digtal knowledge indicator and added the attitude of DFS. Several items were added, referring to s on financial knowledge variables. The $\mathrm{s}$ and items on the financial attitude variable, in this table below:

Table 3. Indicator and Item of Financial Attitude

\begin{tabular}{lll}
\hline \multicolumn{1}{c}{ Indicator } & \multicolumn{1}{c}{ Item } \\
\hline 1. Attitude toward money & 1. Satisfaction when shopping \\
& 2. Financial integrity and responsibility \\
2. Attitude toward purchasing power & 1. Purchase as needed \\
& 2. Management of expenses when income increases \\
& 3. Purchase according to ability \\
3. Attitude toward personal finance & 1. knowledge of the basics of finance \\
management & 2. enlarge the source of income \\
& 3. expense management \\
& 4. personal financial management \\
& 5. budgeting \\
4. Attitude toward saving and & 7. financial goal \\
investment & 1. Attitude toward saving \\
5. Attitude towars loan & 2. Attitude toward investment \\
& 1. Attitude toward loan \\
6. Attitude toward protection & 2. Attitude towards consumptive loans \\
7. Attitude toward DFS & 3. Attitudes towards productive loans \\
& 1. Attitude toward protection \\
& 1. DFS in financial management \\
\hline
\end{tabular}

\section{d) Financial Behaviour}

Financial behavior refers to positive financial behavior that can shape a financial situation, financial well-being, and financial satisfaction. To measure this variable, indicators are used, adopted from OJK (2013), OEDC, 2016, and OEDC, 2018 [33], [25], [21].

Table 4. Indicator and Item of Financial Behaviour

\begin{tabular}{ll}
\hline \multicolumn{1}{c}{ Indicator } & \multicolumn{1}{c}{ Item } \\
\hline 1. Financial control & 1. Behavior towards money \\
2. Purchasing behavior & 2. Behavior towards obligations \\
& 1. Purchase as needed \\
& 2. Purchases when your income increases \\
3. Personal finance management & 3. Purchase according to capacity \\
& 1. Efforts to find information on basic finance \\
& 2. Personal finances management \\
& 3. Budgeting \\
& 4. Financial goal \\
4. Saving behavior and investment & 1. Sinancial planning \\
behavior & 2. Investment \\
5. Loan & 1. Consumptive loan \\
\end{tabular}




\begin{tabular}{ll}
\hline \multicolumn{1}{c}{ Indicator } & \multicolumn{1}{c}{ Item } \\
\hline 6. Protection & 1. Protection \\
7. Use of DFS & 1. Use of digital banking / digital banking services \\
& 2. Use of digital payments \\
& 3. Use of E-commerce \\
4. Use of digital investment / digital investment & 5. Use of digital lending / digital loans \\
& 6. Use od digital insurance \\
7. Purchase behavior with DFS \\
8. Personal finances management using DFS \\
9. Savings behavior \\
10. Investing behavior \\
11. Loaning behavior \\
12. Behavior in financial protection
\end{tabular}

\section{e) Financial Satisfaction}

Financial satisfaction is satisfaction refers to a person's feelings regarding all aspects of his financial situation. The indicators for measuring this variable are summarized in two indicators, namely adopted from Arifin, 2018 and Saurabh \& Nandan, 2018 [7], [11].

Table 4. Indicator and Item of Financial Behaviour

\begin{tabular}{ll}
\hline \multicolumn{1}{c}{ Indicator } & \multicolumn{1}{c}{ Item } \\
\hline 1. Actual financial condition & 1. Saving \\
& 2. Loan \\
& 3. Ability to meet needs \\
$\begin{array}{ll}\text { 2. Subjective assessment of } \\
\text { financial condition }\end{array}$ & 1. Financial welfare satisfaction; \\
\hline
\end{tabular}

\section{Conclusions}

This research is a conceptual paper that develops a research model for use in further research. Through the TRA and TPB approaches, a research model is obtained related to financial knowledge, digital financial knowledge, financial attitude, financial behavior, and financial satisfaction. So far, researchers have not found previous research that examines financial behavior and financial satisfaction associated with digital financial knowledge. Therefore, indicators and items in the digital financial knowledge variable refer to the competencies proposed by OEDC and Morgan. The research model proposed is aimed at researching millennials, because of their characteristics. In the future, the instruments developed in this study can be developed more widely and used in further research.

\section{Acknowledgements}

I would like to thank the supervisor who has directed and give constructive input on this research.

\section{References}

[1] OECD, "G20/OECD INFE Policy Guidance on Digitalisation and Financial Literacy," 
pp. 1-25, 2018, [Online]. Available: http://www.oecd.org/finance/G20-OECD-INFEPolicy-Guidance-Digitalisation-Financial-Literacy-2018.pdf.

[2] OJK, "DIGITAL FINANCE INNOVATION ROAD MAP AND ACTION PLAN 2020-2024," vol. 1st Produc, no. DIGITAL FINANCE INNOVATION ROAD MAP AND ACTION PLAN 2020-2024, p. 52, 2020.

[3] H. Prasad, D. Meghwal, and V. Dayama, "Digital Financial Literacy: A Study of Households of Udaipur," J. Bus. Manag., vol. 5, no. 5, pp. 23-32, 2018, doi: 10.3126/jbm.v5i0.27385.

[4] P. J. Morgan, B. Huang, and L. Q. Trinh, "The Need to Promote Digital Financial Literacy for the Digital Age," Adb.Org, pp. 40-46, 2019, [Online]. Available: https://www.adb.org/sites/default/files/publication/503706/adbi-realizing-education-alldigital-

age.pdf\#page=56https://www.adb.org/sites/default/files/publication/503706/adbirealizing-education-all-digital-age.pdf $\% 23$ page $=56$.

[5] H. Ali, L. Purwandi, H. Nugroho, A. W. Ekoputri, and T. Halim, "The Urban MiddleClass Indonesia: Financial and Online Behavior," Alvara Res. Cent., 2017, [Online]. Available: https://alvara-strategic.com/wp-content/uploads/whitepaper/The-UrbanMiddle-Class-Millenials.pdf.

[6] W. P. Utomo, “Indonesia Millennial Report 2019," IDN Res. Inst., vol. 01, p. 61, 2019, [Online]. Available: https://www.idntimes.com/indonesiamillennialreport2019.

[7] A. Z. Arifin, "Influence Factors toward Financial Satisfaction with Financial Behavior as Intervening Variable on Jakarta Area Workforce," vol. XXI, no. 1, pp. 90-103, 2018.

[8] S. Joo and J. E. Grable, "An Exploratory Framework of the Determinants," vol. 25, no. 1, pp. 25-50.

[9] L. Falahati, M. F. Sabri, and L. H. J. Paim, "Assessment a model of financial satisfaction predictors: Examining the mediate effect of financial behaviour and financial strain," World Appl. Sci. J., vol. 20, no. 2, pp. 190-197, 2012, doi: 10.5829/idosi.wasj.2012.20.02.1832.

[10] C. de B. Scheresberg, "Numeracy Advancing Education in Quantitative Literacy Financial Literacy and Financial Behavior among Young Adults: Evidence and Implications," Sch. Commons, vol. 6, no. 2, pp. 1-23, 2013, doi: 10.5038/19364660.6.2.5.

[11] K. Saurabh and T. Nandan, "Role of financial risk attitude and financial behavior as mediators in financial satisfaction Empirical evidence from India," vol. 7, no. 2, pp. 207-224, 2018, doi: 10.1108/SAJBS-07-2017-0088.

[12] "RELATIONSHIP BETWEEN FINANCIAL SATISFACTION AND FINANCIAL LITERACY : EXPLORING," vol. 305, 2016.

[13] L. Riitsalu and R. Murakas, "Subjective financial knowledge, prudent behaviour and income: The predictors of financial well-being in Estonia," Int. J. Bank Mark., vol. 37, no. 4, pp. 934-950, 2019, doi: 10.1108/IJBM-03-2018-0071.

[14] T. B. Ramalho and D. Forte, "Financial literacy in Brazil - do knowledge and selfconfidence relate with behavior?," RAUSP Manag. J., vol. 54, no. 1, pp. 77-95, 2019, doi: 10.1108/RAUSP-04-2018-0008.

[15] A. W. Awan and J. A. Jamali, "Impact of Corporate Governance on Financial Performance: Karachi Stock Exchange, Pakistan,” Bus. Econ. Res., vol. 6, no. 2, p. 401, 2016, doi: 10.5296/ber.v6i2.9772.

[16] I. Budiati et al., "Profil Generasi Milenial Indonesia," pp. 1-153, 2018, [Online]. 
Available: www.freepik.com.

[17] S. J. Huston, "Measuring Financial Literacy," vol. 44, no. 2, pp. 296-316, 2010.

[18] S. J. Huston, "Measuring Financial Literacy," J. Consum. Aff., vol. 44, no. 2, pp. 296316, 2010, doi: 10.1111/j.1745-6606.2010.01170.x.

[19] A. Lyons, J. Kass-Hanna, F. Liu, A. Greenlee, and L. Zeng, Building Financial Resilience Through Financial and Digital Literacy in South Asia and Sub-Saharan Africa. 2019.

[20] OECD, "G20/Oecd Infe Core Competencies Framework on Financial Literacy for Adults G20/Oecd Infe Core Competencies Framework on Financial Literacy for Adults G20/Oecd Infe Report on Adult Financial Literacy in G20 Countries,” pp. 1-80, 2017, [Online]. Available: www.financial-education.org.

[21] OECD/INFE, "OECD/INFE Toolkit for Measuring Financial Literacy and Financial Inclusion," Oecd, no. March, 2018.

[22] N. Tony and K. Desai, "Impact of digital financial literacy on digital financial inclusion," Int. J. Sci. Technol. Res., vol. 9, no. 1, pp. 1911-1915, 2020.

[23] I. Ajzen, "The theory of planned behavior," Organ. Behav. Hum. Decis. Process., vol. 50, no. 2, pp. 179-211, 1991, doi: 10.1016/0749-5978(91)90020-T.

[24] N. Garg and S. Singh, "Financial literacy among youth," Int. J. Soc. Econ., vol. 45, no. 1, pp. 173-186, 2018, doi: 10.1108/IJSE-11-2016-0303.

[25] A. Atkinson, C. Monticone, and F. A. Mess, "OECD/INFE International Survey of Adult Financial Literacy Competencies," Oecd, pp. 1-100, 2016.

[26] R. Anthony, W. S. Ezat, S. Al Junid, and H. Moshiri, "Financial Management Attitude and Practice among the Medical Practitioners in Public and Private Medical Service in Malaysia," Int. J. Bus. Manag., vol. 6, no. 8, pp. 105-113, 2011, doi: 10.5539/ijbm.v6n8p105.

[27] S. Co, "Understanding Factors Affecting Financial Satisfaction: The Influence of Financial Behavior , Financial Knowledge and Demographics," no. 5, pp. 377-385, 2016.

[28] J. J. Xiao and N. Porto, "Financial education and financial satisfaction: Financial literacy, behavior, and capability as mediators," Int. J. Bank Mark., vol. 35, no. 5, pp. 805-817, 2017, doi: 10.1108/IJBM-01-2016-0009.

[29] B. K. Hasibuan, Y. M. Lubis, and W. A. HR, "Financial Literacy and Financial Behavior as a Measure of Financial Satisfaction,” vol. 46, no. Ebic 2017, pp. 503-507, 2018, doi: 10.2991/ebic-17.2018.79.

[30] W. D. Wattles, The Science of Getting Rich. USA: Springer, 2007.

[31] A. Z. Arifin, "The Influence of Financial Knowledge, Control and Income on Individual Financial Behavior," vol. XX, no. 3, pp. 635-648, 2017.

[32] OECD/INFE, "Fostering digital literacy and well-being." https://www.oecdilibrary.org/sites/23ac808e-en/index.html?itemId=/content/component/23ac808e-en (accessed Sep. 01, 2020).

[33] Otoritas Jasa Keuangan, "Developing Indonesian Financial Literacy Index," DEFINIT.Asia, 2013, [Online]. Available: http://www.definit.asia/researchproject6.html.

[34] J. Augustin, S. Worokinasih, and A. Darmawan, "Peran Mediasi Financial Behaviour Pada Financial Literacy Terhadap Firm Performance," Profit, vol. 14, no. 2, pp. 92 103, 2020, doi: 10.21776/ub.profit.2020.014.02.11. 